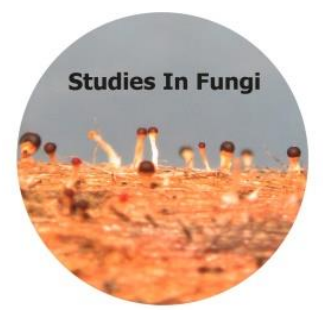

Studies in Fungi 3(1): 234-240 (2018) www.studiesinfungi.org ISSN 2465-4973

Article

Doi 10.5943/sif/3/1/23

Copyright $\odot$ Institute of Animal Science, Chinese Academy of Agricultural Sciences

\title{
A new record to rust fungi of North Western Himalayas (Himachal Pradesh), India
}

\section{Gautam AK ${ }^{1}$ and Avasthi $S^{2}$}

${ }^{1}$ School of Agriculture, Faculty of Science, Abhilashi University, Mandi - 175028, Himachal Pradesh, India

${ }^{2}$ Department of Botany, Abhilashi Post Graduate Institute of Sciences, Mandi - 175008, Himachal Pradesh, India

Gautam AK, Avasthi S 2018 - A new record to rust fungi of North Western Himalayas (Himachal Pradesh), India. Studies in Fungi 3(1), 234-240, Doi 10.5943/sif/3/1/23

\begin{abstract}
A rust fungus occurring on bamboo leaves from Bilaspur, Himachal Pradesh, North India is described and illustrated. A critical morphological and microscopic examination revealed it to be Kweilingia divina. It is the synonym of Dasturella divina, the type species for the fungal genus Dasturella, named in 1943 from infected leaf samples of bamboo (Bambusa sp.). After conducting a literature survey it was found that this fungus is the first to be reported from North Western Himalayas. A detailed taxonomic description of this fungus along with its distribution is provided.
\end{abstract}

Key words - bamboo - Puccinales - systematics - taxonomy

\section{Introduction}

Rust fungi are highly specialized obligate plant parasites having unique systematic characteristics among all fungal groups. These fungi commonly appear as yellow orange or brown powder on a variety of host plants with an estimated 168 rust genera and approximately 7000 species (Mohanan 2010). These fungi require an average temperature of up to $35^{\circ} \mathrm{C}$ along with 50$60 \%$ relative humidity to initiate an infection on host. Once these pathogens are established on the infected host, they produce pale chlorotic leaf spots which eventually develop into spore-producing structures called pustules or sorus on different plant parts, mainly leaves, but also on leaf stalks (petioles), stems and rarely, on flowers and fruit. These pustules may be of orange, yellow, brown, black or white in colour. The infection by rust pathogen may often reduce the vigour of the plant. However, the infected plant may be killed in extreme cases (Peterson 1974, Cummins \& Hiratsuka 2003, Mohanan 2010).

Bamboos comprise a large group of evergreen perennial flowering plants in the grass family Poaceae with more than 115 genera and 1400 species. They are distributed in tropical and subtropical to mild temperate regions of the world and cover about 21 million hectares of the earth surface as bamboo forests. A largest number of these species occurred in East and Southeast Asia (Dransfield \& Widjaja 1995, Hyde et al. 2002) and on islands of the Indian and Pacific oceans. In India, there are about 128 species of bamboos belonging to 23 genera covering an area of 10.03 million hectares, which constitute around $12.8 \%$ of the total area of forest cover in the country (Tiwari 1992). As in other living plants, rust disease on bamboo is one of the biggest problems worldwide, occurring at any growth and developmental stage of the plants i.e. in nurseries, plantations, as well as in natural stands. A recent review on microbes associated with bamboo in the 
Indian subcontinent revealed that there are 432 microbes found associated with bamboo belonging to 12 phyla and 46 orders as saprobes, pathogens and also as symbionts (Remadevi et al. 2017).

During routine field explorations we collected rust fungi on bamboo leaves from district Bilaspur, Himachal Pradesh, North India. Critical morphological examination of the diseased leaf samples revealed it to be a species of Kweilingia. A detailed literature survey and comparative analyses (Mukherji \& Juneja 1974, Bilgrami et al. 1991, Jamaluddin et al. 2004) revealed that this fungus is the first record for North Western Himalayas. Therefore, a detailed taxonomic description of the species is provided.

\section{Materials \& Methods}

Infected leaf specimens of bamboo (Dendroclamus strictus) were collected during winter (October 2017) into paper bags and taken to the laboratory for identification and taxonomical studies. The rust sori were studied with the help of magnifying lens and examined under a stereomicroscope. Free hand sections were taken along with rust symptoms. Microscopic slides were also prepared from air-dried specimens stained with hydrous lactophenol cotton blue stain and observed under a light microscope. For microscopic characters and photographs a research microscope connected with Sony DSC camera was used. All measurements were taken with the help of ToupView software. Identified samples were deposited in the Abhilashi University Mycological Herbarium (AUMH), Abhilashi University, Mandi, Himachal Pradesh, India.

\section{Results}

Initial symptoms appeared in the form of small water-soaked, pinhead-sized greyish brown minute flecks on the lower surface of leaves which later coalesced to form spindle shaped dark brown pustules. The disease symptoms usually appeared in the month of August and last up to May, the following year. Interestingly, the infection was limited to mature leaves and no rust symptoms were found on juvenile or young leaves. The development of fungal sori was observed as brown or black longitudinal streaks mainly on the adaxial surface of leaves. The detailed descriptions and illustrations (Fig. 1) of the fungi along with a discussion on its taxonomy and distribution (Fig. 2) are presented below.

\section{Taxonomy}

Kweilingia divina (Syd.) Buriticá 1998

Fig. 1

= Dasturella divina (Syd.) Mundk. \& Khesw. 1943

= Caeoma divinum Syd. 1931

= Angiopsora divina Syd. 1936

Uredial sorus yellowish orange to brown, hypophyllous, solitary or in small strips, erumpent, brown, paraphysate, measuring 190-435 $\times 20-90 \mu \mathrm{m} \quad(\overline{\mathrm{x}}=296 \times 45 \mu \mathrm{m}, \mathrm{n}=25)$; urediospores brown, sessile, globose to pyriform, echinulate, measuring $20-40 \times 12-25 \mu \mathrm{m}(\overline{\mathrm{x}}=$ $27.2 \times 16.4 \mu \mathrm{m}, \mathrm{n}=30$ ), wall $1-3 \mu \mathrm{m}$ thick.

Telial sorus hypophyllous, dark brown surrounded by yellowish-brown discolouration, solitary (occasionally $2-3$ sori coalesced), sub-epidermal, erumpent, non- paraphysate, measuring 150-200 $\times$ 85-175 $\mu \mathrm{m}(\overline{\mathrm{x}}=290 \times 160 \mu \mathrm{m}, \mathrm{n}=30)$; teliospores sessile, cinnamon brown, catenulate, 3-6-celled, measuring $15-40 \times 5-16 \mu \mathrm{m}(\overline{\mathrm{x}}=34.6 \times 11.8 \mu \mathrm{m}, \mathrm{n}=30)$, with wall 1-2 $\mu \mathrm{m}$ in thickness.

Known distribution - worldwide in distribution (Africa, Colombia, Brazil, Central America and Australia and most of Asia). Reported in India from Rajasthan, Karnataka, Maharashtra, Kerala, Uttar Pradesh, Andhra Pradesh and Himachal Pradesh (Fig. 2).

Material examined - India, Himachal Pradesh, Bilaspur, $673 \mathrm{~m}$, on leaves of Dendroclamus strictus, 25 December 2017, AK Gautam \& S. Avasthi, AUMH-1033 (holotype). 


\section{Discussion}

Kweilingia divina (Syd.) Buriticá is the synonym of Dasturella divina (Syd.) Mundk. \& Khesw., the type species of Dasturella, introduced in 1943 from infected leaf samples of bamboo (Bambusa sp.) (Mundkur \& Kheswalla 1943). In 1998, Dasturella divina Mundk. \& Khesw. was renamed as Kweilingia divina (Syd.) Buriticá. The rust caused by this fungus is an important disease in bamboo plantations throughout the globe. As this disease mainly appeared on leaves, the reduction in photosynthetic activity as well food production is obvious in bamboo plants. This ultimately affects the overall growth and vigor of infected bamboo plants (Mohanan \& Liese 1990, Mohanan 1997).

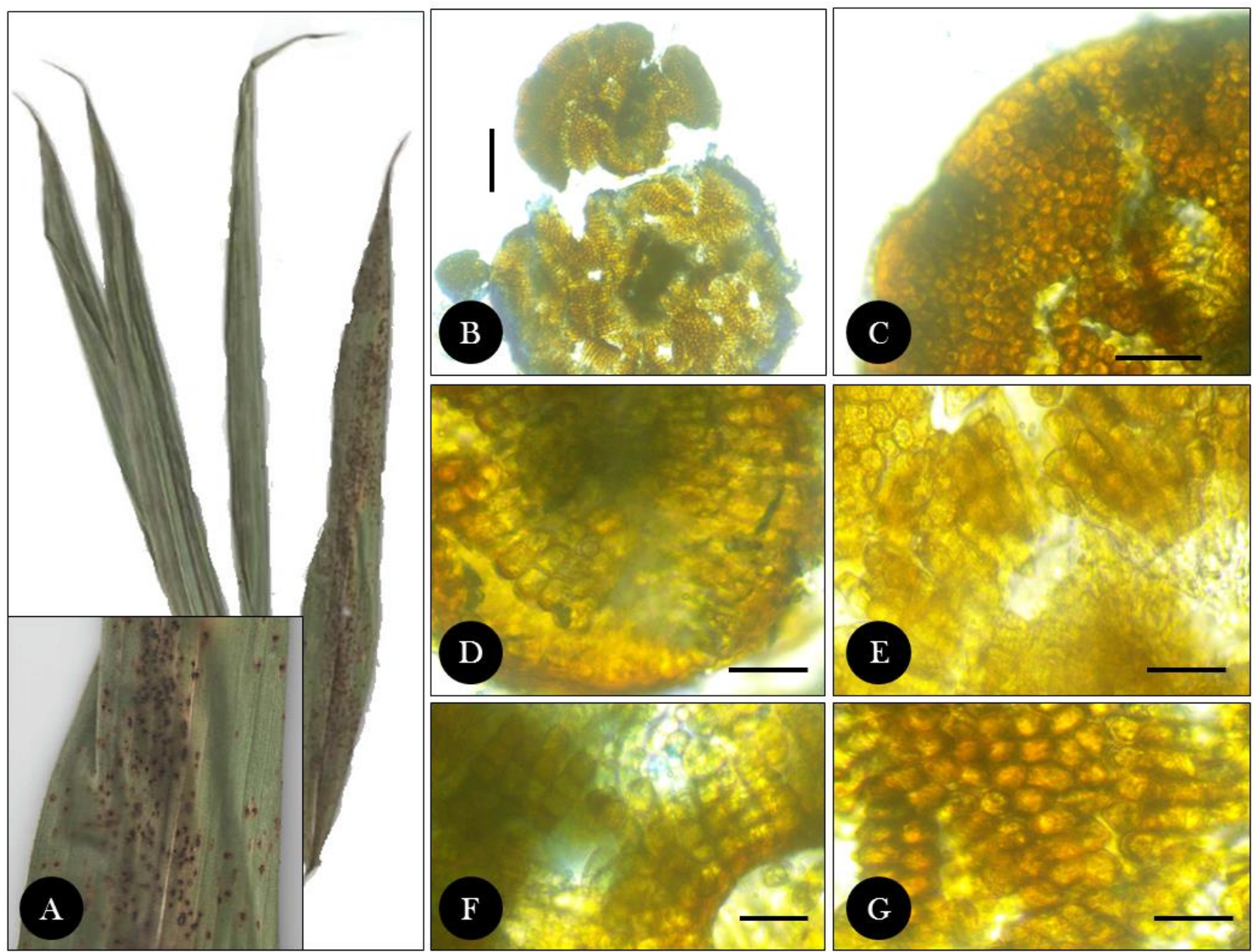

Fig. 1 - Kweilingia divina (AUMH-1033, holotype). A, B Telial sorus on infected leaves. C Telial sori. D-G Teliospores. Scale Bars: $b=100 \mu \mathrm{m} ; \mathrm{C}-\mathrm{G}=20 \mu \mathrm{m}$.

Bamboo rust caused by Kweilingia (Dasturella) divina has a worldwide distribution mainly in parts of Asia but has also been found in Africa, Colombia, Brazil, Central America (Farr \& Rossman 2018, Blomquist et al. 2009) and Australia (Johnson 1985). In India, reports and studies on bamboo fungi have been made by various researchers (Mohanan 1994, 2002, Hosagoudar 2013). However, this rust fungus has already been reported from various localities in India. The detailed information on previous reports of K. divina along with other Dasturella spp. from in India is provided in Table 1.

Kweilingia divina is a heteroecious rust fungi that requires two hosts to complete its life cycle. It produces urediniospores and teliospores on bamboo leaves while spermatia (pycniospores) and aeciospores on its alternate host (Cummins 1971). The alternate hosts are reported as: aecidial stage on leaves of Randia brandisi and $R$. candolleana from Walayar, Tamil Nadu and Chittoor, 
Aadhra Pradesh (Munjal et al. 1960); pycnidia and aecia on Randia dumetorum (Thirumalachar \& Gopalkrishnan 1947), Randia uliginosa Khnadala from Maharashtra (Thirumalachar et al. 1956) and on Randia sp. from Polibetta, Coorg, Karnataka (Rangaswami et al. 1970).

Although, a number of reports on the occurrence of bamboo rust caused by Kweilingia divina from various locations of India are available, there has been no report from Himachal Pradesh so far. Therefore, we present this as a new record of rust fungi for Himachal Pradesh, India in North Western Himalaya.

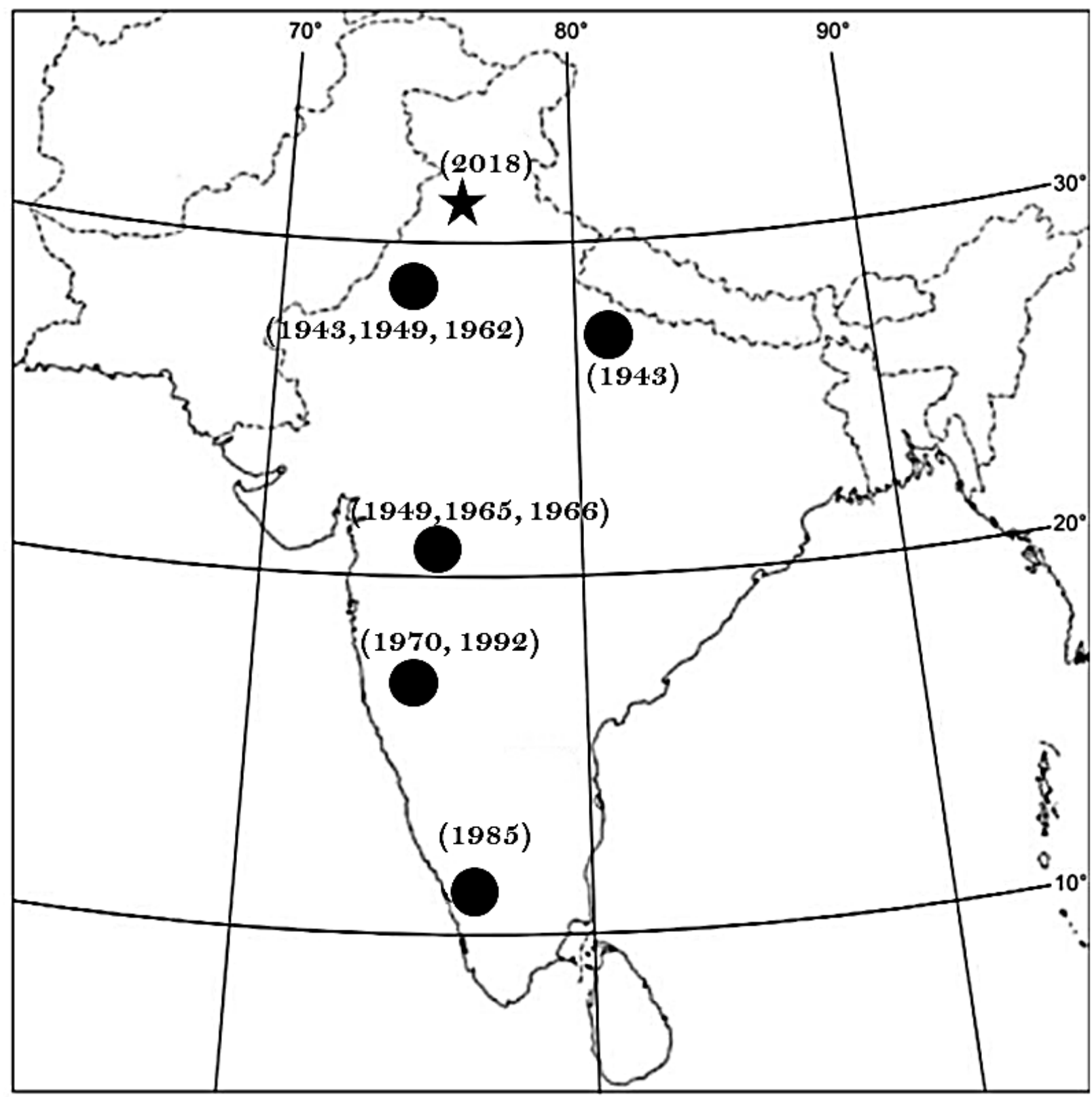

Fig. 2 - Distributional map of Kweilingia divina (Syd.) Buriticá in India ( $\$ $\mathbf{x}$ current report).

Table 1 Genus Dasturella recorded from India, host, location and references.

\begin{tabular}{|c|c|c|c|}
\hline Species & Host & Location & Reference \\
\hline $\begin{array}{l}\text { Dasturella } \\
\text { bambusina Mundk. \& } \\
\text { Khesw. }\end{array}$ & $\begin{array}{l}\text { Bambusa } \\
\text { nutans, } \\
\text { B. vulgaris, } \\
\text { Bambusa spp. }\end{array}$ & $\begin{array}{l}\text { Jabalpur (Madhya } \\
\text { Pradesh), Rajasthan, } \\
\text { Mumbai (Maharashtra) }\end{array}$ & $\begin{array}{l}\text { Mundkur \& Kheswala (1943), Patel et al. } \\
\text { (1949), Nema \& Mishra (1965), Tyagi et al. } \\
\text { (1984), Khan et al. (1995), Mohanan (2002) }\end{array}$ \\
\hline
\end{tabular}


Table 1 Continued.

\begin{tabular}{|c|c|c|c|}
\hline Species & Host & Location & Reference \\
\hline $\begin{array}{l}\text { Kweilingia } \\
\text { divina (Dasturella } \\
\text { divina) (Syd.) Mundk. } \\
\text { \& Khesw. }\end{array}$ & $\begin{array}{l}\text { Bambusa bambos, B. } \\
\text { bambos, B. balcooa, } \\
\text { B. multiplex, B. } \\
\text { tuldoides, B. vulgaris, } \\
\text { B. ventricosa, B. } \\
\text { arundinacea, B. } \\
\text { nutans, } \\
\text { Bowsella serrate, } \\
\text { Dendroclamus } \\
\text { brandisii, D. strictus, } \\
\text { D. hamiltonii, D. } \\
\text { longispathus, } \\
\text { Dendrocalamus sp., } \\
\text { Ochlandra } \\
\text { travancorica, } \\
\text { O. scriptoria, } \\
\text { O. monostigma, } \\
\text { Oxytenanthera } \\
\text { abeysannae, } \\
\text { Phyllostachys } \\
\text { ritcheyi, } \\
\text { Thyrsostachys } \\
\text { siamensis, } \\
\text { T. oliveri, } \\
\text { T. siamensis }\end{array}$ & $\begin{array}{l}\text { Dandeli (Mysore - } \\
\text { Karnataka), } \\
\text { Dehradun } \\
\text { (Uttarakhand), } \\
\text { Dharwad (Karnataka), } \\
\text { Idukki (Kerala), } \\
\text { Majhgwan \& } \\
\text { Shararanpur (Uttar } \\
\text { Pradesh), } \\
\text { Mahableshwar \& Poona } \\
\text { (Maharashtra), } \\
\text { Kumarpet } \\
\text { (Vishakhapatnam - } \\
\text { Aadhra Pradesh), } \\
\text { Dharwad (Karnataka), } \\
\text { Rajasthan }\end{array}$ & $\begin{array}{l}\text { Bakshi \& Singh (1967), Bakshi et al. } \\
\text { (1972), Bhat (1992), Hosagoudar (1985), } \\
\text { Jamaluddin (1992), Khan et al. (1995), } \\
\text { Mohanan (1988, 2002, 2006, 2008), } \\
\text { Mundkar \& Kheshwala (1943), Sathe } \\
\text { (1965), Patel et al. (1949, 1951), Patil } \\
\text { (1966), Rangaswami et al. (1970), Tewari } \\
\text { (1992), Tyagi et al. (1962), } \\
\text { Udayan \& Balachandran (2009) }\end{array}$ \\
\hline $\begin{array}{l}\text { Dasturella boswelliae } \\
\text { Patel, Payak \& N.B. } \\
\text { Kulk. }\end{array}$ & Boswellia serrata & $\begin{array}{l}\text { Hanuman Hill, Poona } \\
\text { (MS) }\end{array}$ & Patel et al. (1951) \\
\hline $\begin{array}{l}\text { Dasturella } \\
\text { grewiae (Pat. \& Har.) } \\
\text { Thirum. }\end{array}$ & Grewia sp. & Kerela & Thirumalachar (1946) \\
\hline $\begin{array}{l}\text { Dasturella } \\
\text { oxytenantherae }\end{array}$ & $\begin{array}{l}\text { Oxytenanthera sp., } \\
\text { Bambusa sp. }\end{array}$ & $\begin{array}{l}\text { Mahabaleshwar } \\
\text { (Maharashtra) }\end{array}$ & Sathe (1965) \\
\hline Dasturella sp. & Bambusa sp. & Dandeli (Karnataka) & $\begin{array}{l}\text { Rangaswami et al. (1970), Mohanan } \\
(2002)\end{array}$ \\
\hline
\end{tabular}

\section{Acknowledgements}

The authors gratefully thank their respective organizations for providing laboratory facilities to carry out the present research work. We also express our thanks for encouragement and every possible support provided by everyone during this scientific study.

\section{References}

Bakshi BK, Reddy MAR, Puri YN, Singh S. 1972 - Survey of the diseases of important native and exotic forest trees in India. PL-480. Report FRI Dehradun.

Bakshi BK, Singh S. 1967 - Rusts on Indian forest trees. Indian Forest Records (NS). Forest Pathology 2, 139-198.

Bhat MN. 1992 - Dasturella divina - a new record on Bambusa arundinacea from India. Madras Agricultural Journal 79, 222-223.

Bilgrami KS, Jamaluddin, Rizwi MA. 1991 - Fungi of India: list and references. Today and Tomorrow's Printers \& Publishers, New Delhi, India.

Blomquist CL, Aime MC, Orsburn RW, Kinnee SA. 2009 - First Report of Bamboo Rust Caused by Kweilingia divina on Bambusa domestica in Los Angeles County, California. Plant Disease 93, 201. 
Cummins GB, Hiratsuka Y. 2003 - Illustrated Genera of Rust Fungi, Third Edition. American Phytopathological Society Press, Saint Paul, Minnesota.

Cummins GB. 1971 - The rust fungi of cereals, grasses and bamboos. Springer Verlag, New York.

Dransfield S, Widjaja EA. 1995 - Plant Resources of South-East Asia. PROSEA Foundation, Backhuye Puhu, Leiden, The Netherlands.

Farr DR, Rossman AY. 2018 - Fungal Databases, Systematic Mycology and Microbiology Laboratory. Online publication. ARS, USDA, year. Retrieved 23 June 2018, http://nt.arsgrin.gov/fungaldatabases/

Hosagoudar VB. 1985 - Teleomycetes of South India. Indian Phytopathology. 38, 278-281.

Hosagoudar VB. 2013 - My contribution to the fungal knowledge of India. Journal of Threatened Taxa 5, 4129-4348.

Hyde KD, Zhou DQ, Dalisay T. 2002 - Bambusicolous fungi: A review. Fungal Diversity 9, 1-14.

Jamaluddin. 1992 - Diseases of Bamboos in India IDF. Jabalpur paper submitted to ICFRE, Dehradun, India.

Jamaluddin S, Goswami MG, Ojha BM. 2004 - Fungi of India (1989-2001). Scientific Publishers, Jodhpur, Rajasthan, India.

Johnson GI. 1985 - Rust (Dasturella divina) of Bambusa spp. in Australia. Australasian Plant Pathology 14, 54-55.

Khan SN, Misra BM, Tiwari RK. 1995 - New records of pathogenic fungi from India. Indian Journal of Forestry 18, 89-92.

Mohanan C. 1994 - Diseases of bamboos and rattans in Kerala. Kerala Forest Research Institute, Peechi, Thrissur, p. 120.

Mohanan C. 1997 - Diseases of bamboos in Asia. International Network for Bamboo and Rattan, New Delhi, India.

Mohanan C. 2002 - Diseases of Bamboos in Asia: An Illustrated Manual. BRILL publisher, pp. $88-91$.

Mohanan C. 2010 - Rust Fungi of Kerala. Kerala, India: Kerala Forest Research Institute, p .148.

Mohanan C. 2006 - Disease Management in Bamboo Nurseries and Plantations. International training workshop on Bamboo propagation, management and harvesting: Methods, Policy issues and Strategies, pp. 79-90.

Mohanan C. 2008 - Potential diseases and disorders of bamboos in India and their management. International conference on improvement of Bamboo productivity and mMarketing for Ssustainable livelihood, pp. 301-315.

Mohanan C, Liese W. 1990 - Diseases of bamboos. International Journal of Tropical Plant Diseases 8, 1-20.

Mohanan C. 1988 - Diseases of Bamboos in Kerala. Proceedings of the International Bamboo Workshop pp. 173-183.

Mukherji KG, Juneja RC. 1974 - Fungi of India: supplement to the list of Indian Fungi, 19621972. Emkay Publication, Delhi, India.

Mundkur BB, Kheswalla KF. 1943 - Dasturella: a new genus of Uredinales. Mycologia 35, 201206.

Munjal RL, Lali G, Chona BL. 1960 - Some Cercospora species from India IV. Indian Phytopathology 13, 144-149.

Nema KG, Mishra RP. 1965 - The Uredineae of Jabalpur, M.P. Nagpur Agricultural College Magazine 6, 7-9.

Patel MK, Kamat MN, Bhide VP. 1949 - Fungi of Bombay, Supplement I, Indian Phytopathology 2, 142-155.

Patel MK, Payak MN, Kulkarni NB. 1951 - Additions to Fungi of Bombay. II. Indian Phytopathology 4, 71-73.

Patil SD. 1966 - Rust of Mahabaleshwar. The proceedings of the Autumn School in Botany Mahabaleshwar, pp. 254-261.

Peterson R. 1974 - The Rust Fungus Life Cycle. The Botanical Review 40, 453-513. 
Rangaswami G, Sheshadri VS, Lucy Channanna KK. 1970 - Fungi of South India. University of Agriculture Science Bangalore, p. 193.

Remadevi OK, Sharada P, Nagaveni HC. 2017 - An annotated checklist of microbes associated with bamboo in the Indian subcontnent. Journal of Threatened Taxa 9, 10920-10947.

Sathe AV. 1965 - A new species of Dasturella (Uredinales) from India. Sydowia 19, 148-149.

Thirumalachar MJ, Bhat VV, Dhande GW, Patel MK. 1956 - Addition to fungi of Bombay III, Indian Phytopathology 9, 9-14.

Thirumalachar MJ, Gopalkrishnan KS. 1947 - Morphology of spore forms and heteroecism in the giant bamboo rust Dasturella divina. Botanical Gazette 108, 371-379.

Thirumalachar MJ. 1946 - Notes on three South African rusts. Bulletin of the Torrey Botanical Club73, 346-350.

Tiwari DN. 1992 - A monograph on bamboo. International Book Distributors, 498 DehraDun, India, p. 498.

Tyagi RNS, Chitale K, Agnihotri JP. 1962 - Contribution to our knowledge of Uredinales of Rajasthan. Indian Journal of Mycology and Plant Pathology 14, 203-206.

Tyagi RNS, Chitale K, Agnihotri JP. 1984 - Contribution to our knowledge of Uredinales of Rajasthan. Journal of Mycology and Plant Pathology14, 203-206.

Udayan PS, Balachandran I. 2009 - Medicinal Plants of Arya Vaida Sala Herb Garden. Arya Vaidya Sala Kottakkal, Kerala, India. 